\title{
FAKTOR-FAKTOR YANG BERHUBUNGAN DENGAN KUNJUNGAN BALITA KE POSYANDU DI WILAYAH KERJA PUSKESMAS MANGKOSO KABUPATEN BARRU
}

\author{
Factors That Are Related To The Visit Of Children To Posyandu In The \\ MangkosoPuskesmas Working Area, Barru District
}

\author{
Satriani, Syarifuddin Yusuf, Ayu Dwi Putri Rusman \\ (Program Studi Kesehatan Masyarakat Fakultas Ilmu Kesehatan Universitas Muhammadiyah \\ Parepare) \\ (satriani_health@yahoo.com, 085244769858)
}

\begin{abstract}
ABSTRAK
Posyandu merupakan wadah untuk mendapatkan pelayanan dasarterutama dilaksanakan oleh kader yang telah dilatih dibidang kesehatan dan KB, dimana anggotanya berasal dari PKK, tokoh masyarakat dan pemudi. Kader kesehatan merupakan perwujudan peran serta aktif masyarakat dalam pelayanan terpadu, dengan adanya kader yang dipilih oleh masyarakat, kegiatan diprioritaskan pada lima program dan mendapat bantuan dari petugas kesehatan terutama pada kegiatan yang mereka tidak kompeten memberikannya. Penelitian ini bertujuan untuk mengetahui faktor-faktor yang berhubungan dengan kunjungan balita ke posyandu di wilayah kerja Puskesmas Mangkoso Kabupaten Barru. Penelitian ini bersifat analitik dengan pendekatan cross sectional, populasi sebanyak 1.112 balita, sampel penelitian 100 balita. Teknik pengambilan sampel Accidental sampling.Pengumpulan data melalui kuesioner.Penelitian di lakukan di posyandu wilayah kerja Puskesmas Mangkoso pada bulan Juni sampai Juli 2017. Hasil ujichi squaremenunjukkan bahwa yang mempengaruhikunjungan ke posyandu adalah pengetahuan orang tua $(0,000)$, paritas $(0,020)$, status pekerjaan $(0,000)$ dan jarak tempat tinggal $(0,004)$. Disarankan sebagai kesehatan masyarakat masukan tentang kunjungan posyandu balita, partisipasi masyarakat terhadap kunjungan ke posyandu dan sebagai bahan masukkan bagi petugas kesehatan di Puskesmas Mangkoso.
\end{abstract}

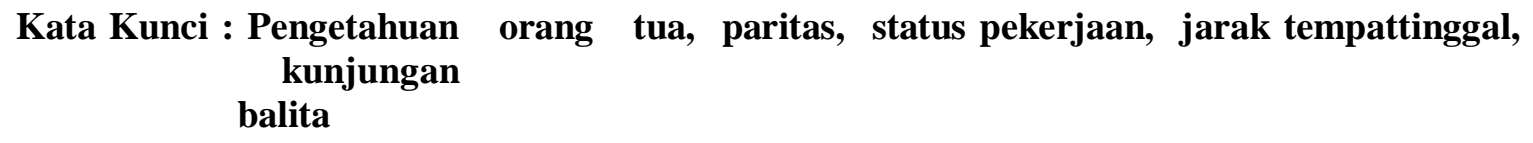

\begin{abstract}
Posyandu is a place to get basic services, especially carried out by cadres who have been trained in the field of health and family planning, where members come from the PKK, community leaders and young women. Health cadres are mandatory community active participation in integrated services, with cadres selected by the community, activities are prioritized in five programs and receive assistance from health workers, especially in activities that they are not competent to provide. This study aims to determine the factors associated with the visit of children under five to posyandu in the working area of Mangkoso Health Center in Barru Regency. This research is analytic with cross sectional approach, a population of 1,112 children under five, a sample of 100 infants. Accidental sampling technique.Data collection through questionnaires. The study was conducted in the Posyandu at the working area of the Mangkoso Community Health Center in June to July 2017. Chi square test results showed that the influence of visits to the posyandu were parental knowledge $(0,000)$, parity $(0.020)$, employment
\end{abstract}


status $(0,000)$ and residence distance (0.004). It is recommended as a public health input about the visit of a toddler posyandu, community participation in a visit to a posyandu and as input material for health workers in the Mangkoso Community Health Center.

Keywords: Parental knowledge, parity, job status, distance of residence, toddler visitation 


\section{PENDAHULUAN}

Posyandu adalah salah satu bentuk Upaya Kesehatan Bersumber Daya Masyarakat (UKBM) yang dikelola dan diselenggarakan dari, oleh, untuk dan bersama masyarakat dalam penyelenggaraan pembangunan kesehatan, guna memberdayakan masyarakat dalam memperolah pelayanan kesehatan dasar untuk mempercepat penurunan angka kematian ibu dan bayi. Posyandu diasumsikan sebagai salah satu pendekatan yang tepat untuk menurunkan angka kematian dan kesakitan balita. ${ }^{1}$

Salah satu upaya pemerintah di bidang kesehatan yang sedang dijalankan untuk menjembatani antara upaya-upaya pelayanan kesehatan profesional dan non profesional yang dikembangkan oleh masyarakat dan keluarga yakni melalui pos pelayanan terpadu yang dikenal dengan sebutan posyandu. ${ }^{2}$ Upaya untuk memasyarakatkan program posyandu di Era pemerintahan Orde Baru terus-menerus dikampanyekan ke masyarakat dengan slogan "Ayo ke posyandu", namun di Era Reformasi berlangsung perkembangan posyandu kelihatannya mengalami kemunduran, karena terkesan pembangunan politik dan ekonomi lebih diprioritaskan dari pada pembangunan sosial, akibatnya pembangunan kesehatan yang berbasis masyarakat sedikit terabaikan, sehingga dampaknya terhadap keberadaan posyandu seolah-olah menjadi "Hidup segan mati tak mau". Salah satu fakta di lapangan dapat kita lihat yaitu adanya kader yang bertugas kurang aktif dan jumlahnya tidak lengkap. ${ }^{3}$ Oleh karena itu telah diterbitkan Surat Edaran Menteri Dalam Negeri dan Otonomi Daerah Nomor : 411.3/1116/SJ tanggal 13 Juni 2000, yang merupakan pedoman Bupati/Walikota di Indonesia tentang revitalisasi posyandu. Dimana diharapkan akan mengembalikan kerja posyandu dan keaktifan-keaktifan kader di dalamnya. ${ }^{4}$

Posyandu merupakan wadah untuk mendapatkan pelayanan dasar terutama dilaksanakan oleh kader yang telah dilatih dibidang kesehatan dan KB, dimana anggotanya berasal dari PKK, tokoh masyarakat dan pemudi. Kader kesehatan merupakan perwujudan peran serta aktif masyarakat dalam pelayanan terpadu, dengan adanya kader yang dipilih oleh masyarakat, kegiatan diprioritaskan pada lima program dan mendapat bantuan dari petugas kesehatan terutama pada kegiatan yang mereka tidak kompeten memberikannya. ${ }^{5}$

Posyandu di Indonesia pada tahun 1985 baru berjumlah sekitar 25.000 Pos, setahun setelah diproses oleh Bapak Presiden meningkat menjadi 185.660 Pos dan tahun 1996 menjadi 244.470 Pos. Hingga tahun 2013, jumlah posyandu yang tersebar di 33 provinsi di Indonesia sekitar 330.000. Posyandu digerakkan oleh para kader secara sukarela yang peduli dengan perkembangan kesehatan anak Indonesia. ${ }^{6}$ 
Bentuk peran serta masyarakat dalam bidang kesehatan adalah Pos Pelayanan Terpadu (Posyandu) yang dibentuk oleh dan untuk masyarakat itu sendiri.Posyandu merupakan salah satu upaya pelayanan kesehatan yang dikelola oleh masyarakat dengan dukungan teknis petugas Puskesmas. Kegiatan Posyandu meliputi 5 program pelayanan kesehatan dasar, yaitu, Kesehatan Ibu dan Anak (KIA), Imunisasi, Keluarga Berencana (KB), Perbaikan Gizi dan Penanggulangan Diare. ${ }^{7}$

Salah satu upaya untuk mengurangi angka kesakitan dan kematian balita adalah dengan melakukan pemeliharaan kesehatannya.Pemeliharaan kesehatan anak balita dititik beratkan kepada upaya pencegahan dan peningkatan kesehatan serta pengobatan dan rehabilitasi yang dapat dilakukan di Puskesmas, Puskesmas Pembantu, Polindes dan di Posyandu, karena Posyandu merupakan tempat yang paling cocok untuk memberikan pelayanan kesehatan pada balita secara menyeluruh dan terpadu. Dengan membawa balita ke Posyandu akan mendapatkan manfaat yaitu anak mendapatkan kesehatan ke arah yang lebih baik, mendapatkan kemudahan pelayanan disatu kesempatan dalam satu tempat sekaligus, dapat menghindari pemborosan waktu, tingkat partisipasi masyarakat mencapai target yang diharapkan dan cakupan pelayanan dapat diperluas sehingga dapat mempercepat terwujudnya peningkatan derajat kesehatan balita. Kunjungan balita di Posyandu berkaitan dengan peran Ibu sebagai orang yang paling bertanggung jawab terhadap kesehatan balitanya, karena balita sangat bergantung dengan Ibunya.Kunjungan Ibu dengan membawa balita ke Posyandu karena adanya motif tertentu misalnya agar anaknya mendapatkan pelayanan kesehatan yang maksimal. Untuk itu, motivasi Ibu dalam pemanfaatan Posyandu balita mempunyai peran yang besar dalam meningkatkan kesehatan balita. ${ }^{8}$

Masalah yang ada perlu ditinjau pengetahuan orang tua, karena pengetahuan merupakan hasil dari "tahu" dan ini terjadi setelah seseorang melakukan penginderaan terhadap suatu objek tertentu. Penginderaan terhadap objek terjadi melalui panca indramanusia yakni penglihatan, pendengaran, penciuman, rasa raba dengan sendiri.

Umur responden 20-35 tahun merupakan umur yang matang maka lebih mudah untuk menerima informasi sehingga dapat meningkatkan pengetahuan ibu tentang posyandu. Pada usia tersebut biasannya ibu sudah mengetahui hal-hal menyangkut posyandu dan sudah berpengalaman khususnya tentang manfaat datang ke posyandu. Hal ini sesuai dengan pendapat bahwa pengalaman pribadi dapat merupakan sumber kebenaran pengetahuan 9

Paritas adalah banyaknya jumlah saudara kandung di dalam keluarga.Jumlah ini di kategorikan pada dua kelompok yaitu keluarga besar dan keluarga kecil. Keluarga besar didefinisikan jika jumlahnya lebih dari dua bersaudara, sedangkan kecil 
didefinisikan jika jumlahnya tidak lebih dari dua bersaudara. ${ }^{10}$

Status pekerjaan ibu umumnya merupakan kegiatan yang menyita waktu. Bekerja bagi ibu- ibu akan mempunyai pengaruh terhadap kehidupan keluarga dan waktu untuk mengasuh anak akan berkurang, sehingga ibu balita yang harus bekerja di luar rumah waktunya untuk berpartisipasi dalam posyandu mungkin sangat kurang bahkan tidak ada sama sekali untuk ikut berpartisipasi di posyandu. Sedangkan pada ibu rumah tangga memungkinkan mempunyai waktu lebih banyak untuk beristirahat dan meluangkan waktu untuk membawa anaknya ke posyandu. Peran ibu yang bekerja dan yang tidak bekerja sangat berpengaruh terhadap perawatan keluarga. Hal ini dapat dilihat dari waktu yang diberikan ibu untuk mengasuh dan membawa anaknya berkunjung ke posyandu masih kurang karena waktunya akan habis untuk menyelesaikan semua pekerjaan. Aspek ini yang berhubungan dengan alokasi waktu adalah jenis pekerjaan, tempat ibu bekerja serta jumlah waktu yang dipergunakan untuk keluarga di rumah. ${ }^{11}$

Jarak tempat tinggal ke posyandu, yang dimaksud dengan jarak disini adalah ukuran jauh dekatnya dari rumah atau tempat tinggal seseorang ke Posyandu dimana adanya kegiatan pelayanan kesehatan bagi masyarakat di wilayahnya.Jarak adalah ruang sela (panjang atau jauh) antara dua benda atau tempat yaitu jarak antara rumah dengan tempat posyandu. Jarak antara tempat tinggal dengan posyandu sangat mempengaruhi ibu untuk hadir / berpartisipasi dalam kegiatan posyandu. ${ }^{12}$

Kegiatan pemantauan pertumbuhan balita dapat dilihat dengan menggunakan Kartu Menuju Sehat (KMS) balita, dimana balita yang sehat tiap bulan naik berat badannya karena garis pertumbuhan normal seorang balitayang dibuat pada KMS untuk mengetahui seorang anak tumbuh dengan normal atau menyimpang. Dengan cara berkunjung secara teratur ke posyandu untuk ditimbang berat badannya. ${ }^{13}$ Salah satu indikasi pemanfaatan pelayanan kesehatan adalah keaktifan kedatangan masyarakat ke pusat pelayanan tersebut yang dalam hal ini spesifik kepada pemanfaatan pelayanan kesehatan posyandu. Meningkatkan kualitas pelayanan kesehatan di posyandu diperlukan intervensi dari pembina posyandu yaitu puskesmas untuk menjamin pelaksanaan penyuluhan pada ibu bayi dan ibu balita dapat tercapai sesuai dengan target. ${ }^{14}$

Berdasarkan survey awal yang saya lakukan di Puskesmas Mangkoso Adapun jumlah Posyandu yang ada di Puskesmas Mangkoso sebanyak 29 Posyandu dan semuanya aktif dalam melaksanakan kegiatan setiap bulan. Dari jumlah balita yang ada di wilayah kecamatan Mangkoso sebanyak 1.219 balita dan yang mendapat pelayanan kesehatan sebanyak 1.112. ${ }^{15}$

\section{METODE PENELITIAN}

Metode penelitian ini merupakan penelitian survey yang bersifat analitik 
dengan pendekatan cross sectional yaitu untuk mengetahui adanya hubungan pengetahuan orang tua, paritas, status pekerjaan, jarak tempat tinggal dengan kunjungan balita ke posyandu di wilayah kerja Puskesmas Mangkoso Kabupaten Barru. Instrumen yang digunakan pada penelitian ini adalah dengan menggunakan kuesioner yang diberikan ke responden dalam penelitian yang berisi pertanyaanpertanyaan yang menyangkut tentang variabel-variabel yang di teliti. Populasi dalam penelitian ini yaitu ibu yang memiliki balita yang berkunjung ke posyandu di wilayah kerja Puskesmas Mangkoso Kabupaten Barru dengan jumlah 1.112 balita dari 29 posyandu yang ada di wilayah kerja Puskemas Mangkoso. Pengambilan sampel dilakukan dengan teknik Accidental Sampling yaitu metode pengambilan sampel seadanya pada saat penelitian.Perhitungan besar sampel dilakukan dengan menggunakan rumus Slovin. ${ }^{16}$ Jadi jumlah sampel yang digunakan berjumlah 100 balita, dengan teknik pengambilan sampel menggunakan Accidental sampling yaitu balita yang berkunjung ke posyandu di wilayah kerja Puskesmas Mangkoso Kabupaten Barru.Penelitian ini dilakukan di posyandu wilayah kerja Puskesmas Mangkoso Kabupaten Barru pada bulan Juni sampai Juli 2017.

Analisis data dalam penelitian ini dengan menggunakan teknik analisis univariat dan analisis bivariat.Analisis univariat dilakukan terhadap tiap variabel dari hasil penelitian, sedangkan analisis bivariat dilakukan untuk melihat hubungan antara masing-masing variabel independen dan variabel dependen dengan menggunakan uji chi-square $\left(\mathrm{X}^{2}\right)$.

\section{HASIL PENELITIAN}

$\begin{array}{rrcr}\text { Hasil } & \text { penelitian } & \text { Tabel } 1 \\ \text { menunjukkan } & \text { keadaan } & \text { responden }\end{array}$
berdasarkan umur, yaitu responden yang berumur 20 - 25 tahun berjumlah 19 (19\%), responden yang berumur 26 - 30 tahun berjumlah 14 (14\%), responden yang berumur $31-35$ tahun berjumlah 30 (30\%), responden yang berumur 36 - 40 tahun berjumlah 20 (20\%), responden yang berumur $41-45$ berjumlah 17 (17\%). Dengan demikian rata- rata umur responden relatif muda. Berdasarkan jenis kelamin, yaitu yang berjenis kelamin laki - laki berjumlah $12(12 \%)$ dan yang berjenis kelamin perempuan berjumlah 88 (88\%). Dengan demikian hasil di atas menjelaskan bahwa responden lebih banyak yang berjenis kelamin perempuan. Berdasarkanpendidikan terakhir mayoritas responden berpendidikan SD berjumlah $4(4 \%)$, yang pendidikan SMP berjumlah 37 (37\%), yang pendidikan SMA berjumlah $52(52 \%)$ dan yang pendidikan S1 berjumlah 7 (7). Dengan demikian hasil di atas menjelaskan bahwa responden lebih banyak berpendidikanSMA.

Tabel 2 menunjukkan berdasarkan umur balita, yaitu yang berumur 12-23 bulan berjumlah $66(66 \%)$ dan yang berumur 2459 bulan berjumlah 34 (34\%). Dengan demikian hasil di atas menjelaskan bahwa lebih banyak balita yang berumur 12-23 
bulan (Baduta). Berdasarkan jenis kelamin balita, yaitu yang berjenis kelamin perempuan berjumlah 67 (67\%) dan yang berjenis kelamin laki-laki berjumlah 33 (33\%). Dengan demikian hasil di atas menjelaskan bahwa lebih banyak balita yang berjenis kelamin perempuan.

Tabel 3 hasil analisis bivariat menunjukkan bahwa dari 51 responden yang pengetahuan kurang dengan kunjungan balita tidak teratur sebanyak 40 orang dan dari 49 responden yang pengetahuan cukup dengan kunjungan balita teratur sebanyak 35 orang. Berdasarkan hasil uji statistik didapatkan nilai P Value (0.000) berarti ada hubungan pengetahuan orang tua dengan kunjungan balita ke Posyandu di wilayah kerja Puskesmas Mangkoso tahun 2017.

Tabel 4 menunjukkan bahwa dari 56 responden yang paritas atau jumlah anaknya banyak dengan kunjungan balita tidak teratur sebanyak 36 orang dan dari 44 responden yang paritas atau jumlah anaknya 1 dengan kunjungan balita teratur sebanyak 26 orang.Berdasarkan hasil uji statistik didapatkan nilai P Value (0.020) berarti ada hubungan antara paritas atau jumlah anak dengan kunjungan balita ke Posyandu di wilayah kerja Puskesmas Mangkoso tahun 2017.

Tabel 5 untuk status pekerjaan responden seperti yang tertera pada Tabel 5 menunjukkan bahwa dari 7 responden yang status pekerjaan PNS dengan kunjungan balita tidak teratur sebanyak 5 responden, dari 61 responden yang pekerjaan SWASTA dengan kunjungan balita teratur sebanyak 16 responden, dan dari 32 responden yang status pekerjaan URT dengan kunjungan balita tidak teratur sebanyak 7 responden.Hasil uji statistik didapatkan nilai $\mathrm{P}$ value $(0,000)$ berarti ada hubungan antara status pekerjaan ibu dengan kunjungan balita ke Posyandu di wilayah kerja Puskesmas Mangkoso tahun 2017.

Tabel 6 menunjukkan bahwa dari 48 responden yang jarak tempat tinggalnya dekat dengan kunjungan balita tidak teratur sebanyak 21 responden, dan dari 52 responden yang jarak tempat tinggalnya jauh dengan kunjungan balita teratur sebanyak 15 responden.Hasil uji statistik didapatkan nilai $\mathrm{P}$ value $(0,004)$ berarti ada hubungan antara jarak tempat tinggal dengan kunjungan balita ke Posyandu di wilayah kerja Puskesmas Mangkoso Tahun 2017.

\section{PEMBAHASAN}

Pengetahuan merupakan hasil dari "tahu" dan ini terjadi setelah seseorang melakukan penginderaan terhadap suatu objek tertentu. Penginderaan terhadap objek terjadi melalui panca indramanusia yakni penglihatan, pendengaran, penciuman, rasa raba dengan sendiri. Pengetahuan itu sendiri dipengaruhi oleh faktor pendidikan formal. Pengetahuan erat hubungannya dengan pendidikan, dimana diharapkan bahwa dengan pendidikan yang tinggi maka orang tersebut akan semakin luas pula pengetahuannya. Pengetahuan dapat pula diartikan sebagai gejala yang ditemui dan diperoleh manusia melalui pengamatan 
indera.Pengetahuan muncul ketika seseorang menggunakan indera atau akal budinya untuk mengenali benda atau kejadian tertentu yang belum pernah dilihat atau dirasakan sebelumnya.

Berdasarkan hasil penelitian pada Tabel 3 yang telah di lakukan di wilayah kerja Puskesmas Mangkoso menunjukkan bahwa dari 51 responden yang pengetahuan kurang dengan kunjungan balita tidak teratur sebanyak 40 orang dan dari 49 responden yang pengetahuan cukup dengan kunjungan balita teratur sebanyak 35 orang. Hasil uji statistik didapatkan nilai $\mathrm{P}$ Value (0.000) berarti ada hubungan pengetahuan orang tua dengan kunjungan balita ke posyandu di wilayah kerja Puskesmas Mangkoso Tahun 2017. Hasil ini menunjukkan bahwa rata-rata pengetahuan orang tua yang dimiliki kurang karena mayoritas tingkat pendidikan orang tuanya hanya SD, SMP, SMA sederajat dengan jumlah 93 orang. Tingkat pendidikannya yang terbanyak yaitu SMA, namun tidak menuntut kemungkinan bahwa responden yang tingkat pendidikannya SMA memiliki pengetahuan yang tinggi tentang kunjungan balita ke posyandu dibandingkan dengan responden yang memiliki tingkat pendidikan rendah.

Hasil penelitian ini sejalan dengan penelitian yang dilakukan oleh Rinawati (2010) . Melihat hasil pengelolahan data tersebut menunjukkan bahwa pengetahuan orang tua dengan kunjungan balita ke posyandu kurang disebabkan karena pengetahuan orang tua tentang pentingnya posyandu untuk balita di imunisasi atau di timbang tidak banyak memahami apa itu posyandu. Berdasarkan hasil wawancara pada saat penelitian sebagian responden mengatakan mereka tidak memahami betul apa tujuan dan maksud dari posyandu. Sehingga jarang untuk melakukan kunjungan ke posyandu dan pemahaman mereka tentang posyandu kurang karna pengetahuan mereka yang kurang sebagian dari mereka pendidikannya hanya sampai sekolah menengah atas. ${ }^{17}$

Paritas adalah keadaan melahirkan anak baik hidup ataupun mati atau banyaknya kelahiran hidup yang dipunyai oleh seorang wanita.Jumlah saudara adalah banyaknya jumlah saudara kandung di dalam keluarga.Jumlah ini di kategorikan pada dua kelompok yaitu keluarga besar dan keluarga kecil.Keluarga besar didefinisikan jika jumlahnya lebih dari dua bersaudara, sedangkan kecil didefinisikan jika jumlahnya tidak lebih dari dua bersaudara.Pada masa yang lalu banyak pendapat pandangan masyarakat tentang jumlah anak yang tidak sepenuhnya benar. Pendapat tradisional bahwa "Banyak Anak Banyak Rezeki" dan keluarga besar adalah suatu pelayanan luhur terhadap masyarakat telah diganti dengan pendapat bahwa banyak anak banyak susah dan melahirkan banyak anak adalah tindakan yang tidak bertanggung jawab terhadap anak dan masyarakat. Perubahan ekonomi dan perubahan nilai, semuanya terlibat dalam perubahan besarnya jumlah anggota keluarga.Program KB harus dilaksanakan secara intensif untuk menurunkan angka 
fertilitas dan membudayakan Norma Keluarga Kecil Bahagia dan Sejahtera (NKKBS). Salah satu dalam NKKBS adalah tentang jumlah anak yang sebaiknya dimiliki yaitu 2 anak cukup, laki-laki atau perempuan sama saja. ${ }^{10}$

Tabel 4 menunjukkan bahwa dari 56 responden yang paritas atau jumlah anaknya banyak dengan kunjungan balita tidak teratur sebanyak 36 orang dan dari 44 responden yang paritas atau jumlah anaknya 1 dengan kunjungan balita teratur sebanyak 26 orang. Hasil uji statistik didapatkan nilai P Value (0.020) berarti ada hubungan antara paritas atau jumlah anak dengan kunjungan balita ke posyandu di wilayah kerja Puskesmas Mangkoso Tahun 2017. Hasil ini menunjukkan bahwa rata-rata jumlah anak yang dimiliki pengunjung banyak 56 (56\%), disebabkan karena ibu susah mengatur waktu untuk datang ke posyandu karena harus mengurus rumah tangga dan anaknya.

Hasil penelitian ini sejalan dengan penelitian yang dilakukan oleh Rinawati (2010). Melihat hasil pengelolahan data tersebut menunjukkan bahwa dari 56 responden yang paritas atau jumlah anaknya banyak dengan kunjungan balita tidak teratur sebanyak 36 orang dan dari 44 responden yang paritas atau jumlah anaknya 1 dengan kunjungan balita teratur sebanyak 26 orang. Berdasarkan hasil wawancara pada saat penelitian sebagian responden mengatakan mereka sangat sibuk mengurus anaknya serta pekerjaan rumah tangga yang tidak bisa ditinggalkan, sehingga jarang untuk melakukan kunjungan ke posyandu, padahal mereka ingin sekali teratur untuk melakukan kunjungan ke posyandu. ${ }^{17}$

Menurut asumsi peneliti dengan melihat hasil pengelolahan data tersebut menunjukkan bahwa jumlah anak balitanya 1 dengan kunjungan balitanya teratur sedangkan jumlah anak balitanya $>1$ dengan kunjungan balitanya tidak teratur disebabkan karena ibu susah untuk mengatur waktu untuk datang ke posyandu karena harus mengurus rumah tangga dan anaknya. Berdasarkan hasil wawancara pada saat penelitian sebagian responden mengatakan mereka sangat sibuk mengurus anaknya serta pekerjaan rumah tangga yang tidak bisa ditinggalkan, sehingga jarang untuk melakukan kunjungan ke posyandu, padahal mereka ingin sekali teratur untuk melakukan kunjungan ke posyandu.

\section{Pekerjaan adalah pekerjaan yang} harus dilakukan terutama untuk menunjang kehidupannya dan kehidupan keluarga. Pekerjaan bukanlah sumber kesenangan, tetapi lebih banyak merupakan cara mencari nafkah yang membosankan, berulang, dan banyak tantangan. Sedangkan bekerja umumnya merupakan kegiatan yang menyita waktu. Bekerja bagi ibu- ibu akan mempunyai pengaruh terhadap kehidupan keluarga dan waktu untuk mengasuh anak akan berkurang, sehingga ibu balita yang harus bekerja di luar rumah waktunya untuk berpartisipasi dalam posyandu mungkin sangat kurang bahkan tidak ada sama sekali untuk ikut berpartisipasi di posyandu.Sedangkan pada ibu rumah tangga memungkinkan mempunyai waktu lebih 
banyak untuk beristirahat dan meluangkan waktu untuk membawa anaknya ke posyandu. ${ }^{18}$

Tabel 5 menunjukkan bahwa dari 7 responden yang status pekerjaan PNS dengan kunjungan balita tidak teratur sebanyak 5 responden, dari 61 responden yang pekerjaan SWASTA dengan kunjungan balita teratur sebanyak 16 responden, dan dari 32 responden yang status pekerjaan URT dengan kunjungan balita tidak teratur sebanyak 7 responden. Hasil uji statistik didapatkan nilai $\mathrm{P}$ value $(0,000)$ berarti ada hubungan antara status pekerjaan ibu dengan kunjungan balita ke Posyandu di wilayah kerja Puskesmas Mangkoso Tahun 2017. Hasil ini menunjukkan bahwa rata-rata status pekerjaan orang tua balita bekerja, yaitu PNS sebanyak 7 responden (7 \%), SWASTA sebanyak 61 responden $(61 \%)$, dikarena ibu yang bekerja tidak bisa mengatur waktunya untuk datang ke posyandu dibandingkan dengan yang tidak bekerja atau URT sebanyak 32 responden (32\%) yang lebih banyak meluangkan waktunya untuk berkunjung ke posyandu.

Hasil penelitian ini sejalan dengan penelitian yang dilakukan oleh Rinawati (2010).Melihat hasil pengelolahan data tersebut menunjukkan bahwa ibu yang tidak bekerja lebih teratur kunjungan balitanya dari pada ibu yang bekerja.Disebabkan karena ibu yang bekerja tidak bisa mengatur waktunya sehingga waktu mengasuh anaknya tidak ada dan jarang untuk ibu bekerja bisa meluangkan waktunya untuk berkunjung keposyandu.Banyak ibu-ibu bekerja mencari nafkah, baik untuk kepentingan sendiri maupun keluarga.Faktor bekerja saja nampak berpengaruh pada peran ibu yang memiliki balita sebagai timbulnya suatu masalah pada ketidakaktifan ibu kunjungan ke posyandu yang berdampak pada tidak adanya waktu para ibu balita untuk aktif pada kunjungan ke posyandu, serta tidak ada waktu ibu mencari informasi karena kesibukan mereka dalam bekerja.Kondisi kerja yang menonjol sebagai faktor yang mempengaruhi ketidakaktifan. Hal ini dapat menyebabkan rendahnya frekuensi ibu yang memiliki balita untuk kunjungan ke posyandu akan berkurang. ${ }^{17}$

Menurut asumsi peneliti dengan melihat hasil pengelolahan data tersebut menunjukkan bahwa ibu yang tidak bekerja lebih teratur kunjungan balitanya dari pada ibu yang bekerja.Disebabkan karena ibu yang bekerja tidak bisa mengatur waktunya sehingga waktu mengasuh anaknya tidak ada dan jarang untuk ibu bekerja bisa meluangkan waktunya untuk berkunjung kesposyandu. Berdasarkan hasil wawancara pada saat penelitian sebagian responden mengatakan sibuk dengan pekerjaan sehingga tidak sempat untuk datang ke posyandu, dan ada juga mengatakan ibu tersebut lebih banyak waktunya ditempat kerja dari pada dirumah sehingga males untuk ke posyandu.

Jarak adalah ukuran jauh dekatnya dari rumah atau tempat tinggal seseorang ke Posyandu dimana adanya kegiatan 
pelayanan kesehatan bagi masyarakat di wilayahnya. Jarak adalah ruang sela (panjang atau jauh) antara dua benda atau tempat yaitu jarak antara rumah dengan tempat posyandu. ${ }^{17}$

Tabel 6 menunjukkan bahwa dari 48 responden yang jarak tempat tinggalnya dekat dengan kunjungan balita tidak teratur sebanyak 21 responden, dan dari 52 responden yang jarak tempat tinggalnya jauh dengan kunjungan balita teratur sebanyak 15 responden.Hasil uji statistik didapatkan nilai $P$ value $(0,004)$ berarti ada hubungan antara jarak tempat tinggal dengan kunjungan balita ke Posyandu di wilayah kerja Puskesmas Mangkoso Tahun 2017. Hasil ini menunjukkan bahwa rata-rata jarak tempat tinggal balita yang datang ke posyandu jauh, yaitu sebanyak 52 responden (52\%) jarak tempat tinggal responden dengan posyandu sebagian besar jauh sehingga kunjungan ke posyandu tidak teratur, dibandingkan dengan yang jarak tempat tinggalnya dekat sebanyak 48 responden (48\%)

Hasil penelitian ini sejalan dengan penelitian yang dilakukan oleh Rinawati (2010). Melihat hasil pengelolahan data tersebut menunjukkan bahwa jarak tempat tinggal responden dengan posyandu sebagian besar dekat sehingga kunjungan ke posyandu lebih teratur, tetapi bedahalnya dengan jarak tempat tinggal yang jauh mereka tidak teratur untuk melakukan kunjungan posyandu. ${ }^{17}$

Faktor lingkunganfisik/ letak geografis berpengaruh terhadap perilaku seseorang/ masyarakat terhadap kesehatan.
Ibu balita tidak datang ke posyandu disebabkan karena ibu tersebut jauh dengan posyandu sehingga ibu balita tersebut tidak datang untuk mengikuti kegiatan dalam posyandu. ${ }^{16}$ Menurut asumsi peneliti dengan melihat hasil pengelolahan data tersebut menunjukkan bahwa jarak tempat tinggal responden dengan posyandu sebagian besar jauh sehingga kunjungan ke posyandu tidak teratur, tetapi bedahalnya dengan jarak tempat tinggal yang dekat mereka teratur untuk melakukan kunjungan posyandu.Berdasarkan hasil wawancara pada saat penelitian disebakan karena faktor kendaraan yang sulit, jarak tempat tinggal yang jauh karena berada dipendalam menyebabkan responden sulit untuk datang ke posyandu.

\section{KESIMPULAN DAN SARAN}

Berdasarkan hasil penelitian faktorfaktor yang berhubungan dengan kunjungan balita ke posyandu di wilayah kerja Puskesmas Mangkoso Kabupaten Barru, maka dapat ditarik kesimpulan bahwa ada hubungan antara pengetahuan orang tua, paritas, status pekerjaan dan jarak tempat tinggal dengan kunjungan balita ke Posyandu di wilayah kerja Puskesmas Mangkoso Kabupaten Barru. Berdasarkan hasil penelitian tersebut disarankandapat memberikan pemahaman dan pengetahuan mengenai pentingnya kesehatan kunjungan balita ke posyandu, disarankan orang tua yang memiliki anak banyak dan balita, untuk mengatur waktu dan memberikan perhatian yang banyak untuk balita ke posyandu, 
disarankan untuk petugas kesehatan memberikan informasi dan mensurvey lokasi tempat tinggal masyarakat dengan posyandu serta memberikan lokasi pelayanan kesehatan yang mudah di jangkau oleh masyarakat untuk datang ke posyandu, dan diharapkan hasil penelitian ini dapat bermanfaat bagi penelitian selanjutnya terutama dalam hal kunjungan balita ke posyandu di wilayah kerja Puskesmas Mangkoso Kabupaten Barru.

\section{DAFTAR PUSTAKA}

1. Kementerian Kesehatan RI. Riset Kesehatan Dasar 2010. Jakarta; 2011.

2. Kesehatan Masyarakat. Proses Pelaksanaan Manajemen Pelayanan Posyandu Terhadap Intensitas Posyandu :Yokyakarta; 2011.

3. Gemari. Kader Posyandu Membaur Menciptakan Manusia Sehat di Puskesmas Medika; 2010.

4. Departemen Kesehatan RI. Pedoman Umum Pengelolaan Posyandu. Jakarta : Departemen Kesehatan RI, Penerbit Universitas di Ponegoro; 2010.

5. Zulkifli. Posyandu dan Kader Kesehatan. USU : FKM (Fakultas Kesehatan Masyarakat); 2010.

6. Kementerian Kesehatan RI. Kurikulum dan Modul Pelatihan Fasilitator Pemberdayaan Kader Posyandu. Jakarta: Kementerian Kesehatan RI; 2013.

7. Firyadi. Hubungan Pengetahuan dan Sikap Ibu Balita dengan Kunjungan ke Posyandu Kelurahan Bara-Bara Selatan
Wilayah Kerja Puskesmas Bara-Bara Makassar : Universitas Hasanuddin; .2010 .

8. Ayu Idaningsih. Faktor-Faktor yang Berhubungan dengan Kunjungan Balita ke Posyandu. STIKes YPIB Majalengka; 2016.

9. Ali M. Pengetahuan Sikap dan Perilaku Ibu Bekerja dan Tidak Bekerja Tentang Posyandu. Jakarta; 2010.

10. Badan Kependudukan Keluarga Berencana Nasional. Informasi Gerakan KB Nasional, Sasaran Pembangunan Jangka Panjang, Jakarta; 2013.

11. Husnaini. Hubungan antara Pengetahuan dan Motivasi Kader Posyandu dengan Keaktifan Kader Posyandu di Desa Dukuh Tengah Kecamatan Ketanggungan Kabupaten Brebes. Jawa Tengah: Brebes; 2010.

12. Khalimah. Hubungan antara Karakteristik dan Sikap Ibu Balita dengan Praktek Imunisasi Campak di Wilayah Kerja Puskesmas Sekaran Gunung Pati Semarang. Skripsi. Universitas Negeri Semarang; 2011.

13. Departemen Kesehatan RI. Pengantar Kader Posyandu. Jakarta Pusat Promosi Kesehatan Departemen RI; 2011.

14. Werdiningsih. Program-Program Posyandu. Bagian. I. Jakarta; 2011.

15. Puskesmas Mangkoso. Profil Puskesmas Mangkoso Kabupaten Barru; 2016.

16. Notoatmodjo. 2010. Ilmu Perilaku Kesehatan. Jakarta : Rineka cipta.

17. Rinawati. Faktor-faktor yang 
Berhubungan dengan Rendahnya

Kunjungan Balita ke Posyandu di

WilayahKerja Puskesmas Suka

KaryaKota Sabang; 2010.
18. Wawan. Teori dan Pengukuran Sikap dan Perilaku Manusia. Yogyakarta :

Nuha

Medika;

2010. 


\section{LAMPIRAN}

Tabel 1. Distribusi karakteristik responden berdasarkan umur, jenis kelamin, dan pendidikan terakhir dengan kunjungan balita ke Posyandu di Wilayah kerja Puskesmas Mangkoso tahun 2017

\begin{tabular}{|c|c|c|}
\hline Distribusi Responden & $\mathrm{f}$ & $\%$ \\
\hline \multicolumn{3}{|l|}{ Kelompok umur (Tahun) } \\
\hline $20-25$ & 19 & 19 \\
\hline $26-30$ & 14 & 14 \\
\hline $31-35$ & 30 & 30 \\
\hline $36-40$ & 20 & 20 \\
\hline $41-45$ & 17 & 17 \\
\hline \multicolumn{3}{|l|}{ Jenis Kelamin } \\
\hline Laki - laki & 12 & 12 \\
\hline Perempuan & 88 & 88 \\
\hline \multicolumn{3}{|l|}{ Tingkat Pendidikan } \\
\hline $\mathrm{SD}$ & 4 & 4 \\
\hline SMP & 37 & 37 \\
\hline SMA & 52 & 52 \\
\hline \multirow[b]{2}{*}{ Jumlah } & 7 & 7 \\
\hline & 100 & 100 \\
\hline
\end{tabular}

Tabel 2.Distribusi karakteristik identitas balita berdasarkan umur dan jenis kelamin dengan kunjungan balita ke Posyandu di Wilayah kerja Puskesmas Mangkoso tahun 2017

\begin{tabular}{lccc}
\hline & Distribusi Responden & $\mathrm{f}$ & $\%$ \\
\hline Umur (Tahun) & & 66 & 66 \\
$12-23$ bulan (Baduta) & 34 & 34 \\
$24-59$ (Balita) & & \\
\hline Jenis Kelamin & 67 & 67 \\
Laki - laki & 33 & 33 \\
Perempuan & Jumlah & 100 & 100 \\
\hline
\end{tabular}

Tabel 3. Hubungan pengetahuan orang tuadengan kunjungan balita ke posyandu di Wilayah kerja Puskesmas Mangkoso tahun 2017

\begin{tabular}{|c|c|c|c|c|c|c|c|}
\hline \multirow{3}{*}{ Pengetahuan orang tua } & \multicolumn{4}{|c|}{ Kunjungan Balita } & \multirow{2}{*}{\multicolumn{2}{|c|}{ Total }} & \multirow{3}{*}{ P Value } \\
\hline & \multicolumn{2}{|c|}{ Teratur } & \multicolumn{2}{|c|}{ Tidak Teratur } & & & \\
\hline & $f$ & $\%$ & $\mathrm{f}$ & $\%$ & f & $\%$ & \\
\hline Cukup & 35 & 71.4 & 14 & 28.5 & 49 & 100 & \\
\hline Kurang & 11 & 21.5 & 40 & 78.4 & 51 & 100 & 0.000 \\
\hline Total & 46 & 92.9 & 54 & 106.9 & 100 & 100.0 & \\
\hline
\end{tabular}


Tabel 4. Hubungan paritas dengan kunjungan balita ke posyandu di Wilayah kerja Puskesmas Mangkoso tahun 2017

\begin{tabular}{|c|c|c|c|c|c|c|c|}
\hline \multirow{3}{*}{ Paritas } & \multicolumn{4}{|c|}{ Kunjungan Balita } & \multirow{2}{*}{\multicolumn{2}{|c|}{ Total }} & \multirow{3}{*}{ P Value } \\
\hline & \multicolumn{2}{|c|}{ Teratur } & \multicolumn{2}{|c|}{ Tidak Teratur } & & & \\
\hline & $f$ & $\%$ & $\mathrm{f}$ & $\%$ & $\mathrm{f}$ & $\%$ & \\
\hline Banyak & 20 & 35.7 & 36 & 64.2 & 56 & 100 & \\
\hline Sedikit & 26 & 59.0 & 18 & 40.9 & 44 & 100 & 0.020 \\
\hline Total & 46 & 94.7 & 54 & 105.1 & 100 & 100.0 & \\
\hline
\end{tabular}

Tabel 5. Hubunganstatus pekerjaan dengan kunjungan balita keposyandu di Wilayah kerja Puskesmas Mangkoso tahun 2017

\begin{tabular}{|c|c|c|c|c|c|c|c|}
\hline \multirow{3}{*}{ Status Pekerjaan } & \multicolumn{4}{|c|}{ Kunjungan Balita } & \multirow{2}{*}{\multicolumn{2}{|c|}{ Total }} & \multirow{3}{*}{ P Value } \\
\hline & \multicolumn{2}{|c|}{ Teratur } & \multicolumn{2}{|c|}{ Tidak Teratur } & & & \\
\hline & $f$ & $\%$ & $\mathrm{f}$ & $\%$ & $\mathrm{f}$ & $\%$ & \\
\hline PNS & 2 & 28.5 & 5 & 71.4 & 7 & 100 & \\
\hline Swasta & 16 & 26.2 & 45 & 73.7 & 61 & 100 & \\
\hline URT & 25 & 78.1 & 7 & 78.1 & 32 & 100 & 0.000 \\
\hline Total & 43 & 132.8 & 57 & 223.3 & 100 & 100.0 & \\
\hline
\end{tabular}

Tabel 6. Hubungan jarak tempat tinggal dengankunjungan balita keposyandudi Wilayah kerja Puskesmas Mangkoso tahun 2017

\begin{tabular}{lcccccccc}
\hline & \multicolumn{4}{c}{ Jarak tempat tinggal } & \multicolumn{3}{c}{ Keratur } & \multicolumn{2}{c}{ Tidak Teratur } & \multicolumn{2}{c}{ Total } & \multirow{2}{*}{ P Value } \\
\cline { 2 - 7 } & & $\mathrm{f}$ & $\%$ & $\mathrm{f}$ & $\%$ & $\mathrm{f}$ & $\%$ & \\
\hline Dekat & 31 & 64.5 & 21 & 43.7 & 48 & 100 & \\
Jauh & 15 & 28.8 & 33 & 63.4 & 52 & 100 & \multirow{2}{*}{0.004} \\
\hline Total & 46 & 93.3 & 54 & 107.1 & 100 & 100.0 & \\
\hline
\end{tabular}

